\title{
Death Domain-Associated Protein 6
}

National Cancer Institute

\section{Source}

National Cancer Institute. Death Domain-Associated Protein 6. NCI Thesaurus. Code C21260.

Death domain-associated protein $6(740 \mathrm{aa}, \sim 81 \mathrm{kDa})$ is encoded by the human DAXX gene. This protein is involved in the negative regulation of both gene transcription and protein ubiquitination. 